Research Report No. 15/2010

\title{
Corporate Governance and First-Best Solutions: A Sociological Perspective
}

Aviv Pichhadze

Follow this and additional works at: http:/ / digitalcommons.osgoode.yorku.ca/clpe

\section{Recommended Citation}

Pichhadze, Aviv, "Corporate Governance and First-Best Solutions: A Sociological Perspective" (2010). Comparative Research in Law e Political Economy. Research Paper No. 15/2010.

http://digitalcommons.osgoode.yorku.ca/clpe/83 


\title{
OSGOODE
}

OSGOODE HALL LAW SCHOOL

YOR K UN I VERSITY

\section{OSGOODE HALL LAW SCHOOL}

Comparative Research in Law \& Political Economy

\author{
RESEARCH PAPER SERIES
}

Research Paper No. 15/2010

\section{Corporate Governance and First-Best Solution: A SOCIOLOGICAL PERSPECTIVE}

Aviv Pichhadze

\section{Editors:}

Peer Zumbansen (Osgoode Hall Law School, Toronto, Director, Comparative Research in Law and Political Economy)

John W. Cioffi (University of California at Riverside)

Lisa Philipps (Osgoode Hall Law School, Associate Dean Research)

Nassim Nasser (Osgoode Hall Law School, Toronto,

Production Editors) 


\section{Corporate Governance and First-Best Solutions: A Sociological Perspective}

Aviv Pichhadze

Abstract:

Drawing on insights from social science methodology and systems analysis, the article adopts a holistic view of the equity markets and highlights how market forces have been driving the evolution in the equity markets towards a first-best corporate governance model. This governance model is the Market Oriented Blockholder Model (MOBM). The analysis shows that the process is not yet complete given that the legal framework has not yet updated its foundation to fully accommodate the MOBM. Such a failure by policy makers creates an opportunity for the introduction, into the financial system, of regulatory systemic risk - long-term imbalances introduced into the regulatory framework by regulators via regulatory initiatives premised on a distorted understanding of market realities. This is illustrated using the example of the treatment of institutional investors by market participants and regulators.

Keywords:

corporate governance; ownership; institutional investors; regulation; capital markets

Acknowledgements:

Osgoode Hall Law School, York University, Canada. The article is based on a paper presentation at the Association of Transnational Law School (ATLAS) Agora at the London School of Economics and Political Science on 22 June 2009. The article benefited from comments on previous versions by Amir Pichhadze and Ed Waitzer. I would like to extend my gratitude to Jacob A. R. ve YaZi whose support made this study possible. Any errors, omissions as well as the opinions expressed in this paper are my own.

\section{INTRODUCTION}

The ongoing quest for a first-best corporate governance framework appears to be a difficult task. As expressed by Bratton and McCahery (2002, p. 47), "[p]olitics can indeed explain why a governance system has not evolved so as to be first best. But it cannot by itself show us how to improve that system. For that one needs an economic theory of the firm. No economic theory yet articulated shows us how to splice blockholder components onto market systems so as to effect material improvements." Is a first-best framework simply unattainable, or has the quest been misguided? This article will suggest that the first-best governance system is discoverable and, in fact, is actively being unfolded. To identify this, however, one needs to turn to, and understand, the dynamics within the equity markets. These dynamics can be understood and described through the application of sociological methodology.

This analytical exercise is both timely and important as policymakers around the globe are looking to fundamentally reform the global financial system and its various components (OECD 1 2009). These reform initiatives, which are pursued with the view of correcting failures that led to the present economic crisis in a co-ordinated and harmonized manner, cover various levels and components of the financial markets and include such 
things as transparency, risk management, supervision, regulation, and corporate governance (OECD 2 2009). This article is concerned with the last area of proposed reforms - corporate governance.

Harmonization efforts in the area of corporate governance mean that differences resulting from geographic boundaries are lowered in the pursuit of a common goal. Yet, if we are to base our reform efforts on the widely discussed models available in the literature, we run into the familiar problem that has faced policymakers in the area for many years. This was explained by Wymeersch (2002, p. 240), "ownership structure seems the single most significant variable factor in explaining differences in governance structures." hurdle to harmonization efforts given that corporate ownership structures considerably affect many key governance mechanisms (Bebchuk and Hamdani 2009).

Yet, as Pichhadze (2010, pp. 85-86) argued recently, this hurdle is diminishing. This is because we see evidence of global economies moving closer in terms of ownership structures or, stated differently, there is evidence of an emerging global convergence vis-à-vis ownership structures at the level of the markets. This convergence is towards what Pichhadze (2010) referred to as the Market Oriented Blockholder Model (MOBM).

The MOBM is a hybrid ownership structure towards which the US capital markets have been gravitating over the $20^{\text {th }}$ century. The principal feature of the MOBM is its blockholder levels of corporate public ownership, which work harmoniously with market mechanisms (such as takeover activity) to achieve improved monitoring of corporate management along with the development of efficient and liquid markets. As such, the MOBM brings the US closer to the majority of the world's economies that display block holdings. In the US, the emergent blockholder is the institutional investors.

Diminishing, however, does not mean complete removal of the hurdle. This is the result of the distorted view in the literature on corporate governance, or the working hypothesis, which holds that the ownership pattern in the US can be characterized as fragmented (Pichhadze 2010, pp. 71-72). This working hypothesis also resonates within regulatory circles and, consequently, affects the regulatory framework of the capital markets. Accordingly, a situation is created whereby regulatory initiatives that are based on a distorted understanding of the realities in the capital markets affect the overall regulatory framework of these markets to the extent that imbalances are introduced into the regulatory framework imbalances that may result in regulatory systemic risk. ${ }^{2}$

In order to explore the above issues, the analysis adopts Durkheim's (1997) approach and examines the equity markets sui generis - that is, the article takes a holistic view of the capital markets. This type of undertaking is ambitious given the complex nature of the capital markets. Despite this challenge, the exercise is valuable given that it yields results and insight not attained by other modes of analysis.

Part 2 provides a brief overview of systems analysis and introduces the homeostatic and autopoietic processes, as well as, provides examples of their application. Part 3 applies

\footnotetext{
${ }^{1}$ See also statement by Claessens (2003, p. 11) noting, "[t] he nature of the corporate governance problems that countries face varies over time and between countries. One factor of importance is ownership structure ... [which affects] the legal and regulatory infrastructure necessary for good corporate governance ..."

${ }^{2}$ Regulatory systemic risk as contemplated in this article results from a distortion introduced by regulation into the regulatory framework in cases where the foundation underlying regulatory initiatives is inconsistent with market realities and, as a result, such regulatory initiatives do not adequately address the needs of the subject of the regulation. As such, regulatory systemic risk may result in structural imbalances that may, in turn, translate into reduced investor protection.
} 
systems analysis to describe the dynamics within the US equity markets. The purpose, more specifically, is to suggest that Pichhadze's observation, vis-à-vis the MOBM, is the result of unfolding autopoietic and homeostatic processes within these markets when viewed holistically and as a system. As such, the gravitation towards the MOBM is not random but rather the result of the markets' evolution towards an efficient and stable framework, which allows these markets to carry out their functions. Moreover, it is suggested that the MOBM represents the system's realization of the first-best governance framework by allowing the system to accomplish its dual functions of risk allocation and governance. This is in contrast to the existing equity ownership models that promote a realization of one function at the expense of the other.

Part 4 highlights the significance of observing this important trend towards the MOBM from a policy perspective. As the discussion highlights, the failure to take note of the trend poses the risk of introducing a regulatory systemic risk into the financial system. Part 5 will offer some concluding remarks.

\section{SYSTEMS ANALYSIS AND ITS APPLICATIONS}

Systems theory ${ }^{3}$ has been applied to describe and explain the nature of different types of systems, including living organisms, social organizations, and mechanical artefacts. Its application reveals that all systems share several core features. First, a system performs some function(s). Second, the system possesses the mechanisms required for achieving/performing its function(s), and these mechanisms can evolve over time. Third, the sustainability of the system is dependent on its ability to carry out its function(s) in a consistent and stable manner over time, which requires the sustainment/maintenance of a constant framework for the mechanisms by which it operates.

The achievement of internal stability and consistency can be complicated and challenged by influences that may either be external or internal to the system. Thus, while a system is closed to the extent that it seeks to preserve its internal integrity (i.e., the framework by which it performs functions), it is open and vulnerable to influences from other systems and even changes within its own environment.

As the system observes changes to, and instability in, its structural framework (be it due to internal or external factors), the system determines whether, and how, to respond. The system may decide to adapt to the change and evolve. It may do so through the process of self-reproduction (autopoiesis) ${ }^{4}$, whereby it evolves based on its existing framework. Alternatively, it may decide to preserve the status quo, and will apply its self-regulatory mechanisms (homeostasis) to restore its normal condition (Cannon 1932, p. 24). As the system evolves over time, autopoiesis and homeostasis work harmoniously to achieve evolutionary improvements in the system while maintaining the stability and integrity of the system as a whole (Cannon 1932; Shkliarevsky 2007, p. 331). The following examples

\footnotetext{
${ }^{3}$ For a definition of systems theory see, e.g., Audi (1999).

${ }^{4}$ Autopoiesis has its origins in theories of the evolution of cells. There we observe that cells, although evolved and differentiated, communicate with one another to form a complex system of networks. Luhmann (2004)) applied this to the study of social systems and interactions, where each system (e.g., legal, political, etc.) is likened to a cell that communicates with other systems. Such communication, however, is drawn on existing forms of communication, and must be internalized by each system and be benchmarked against each system's existing base knowledge. At that point, the respective systems make a decision whether, and how, to respond to such communications. Some interactions will lead an individual system to effect changes within its system in response to the communication. Other interactions will be less successful. Autopoiesis, then, is a self-referencing mechanism. See also, Maturana and Varela (1980).
} 
illustrate these mechanisms in the contexts of two systems: the human body and the legal system.

\subsection{The Human Body as a System (the Homeostatic Process)}

Cannon (1932) observed that there is an evolutionary development in living systems that affords for an internal consistency (or equilibrium) in such systems through the active regulation of gradients. He called the process homeostasis - a self-regulatory process that involves the restoration and preservation of a constant state in the body despite influences that may disturb the body's equilibrium state. The sustainability of the organism is dependent on its ability to maintain consistency via homeostasis. Key to the homeostatic process is the flow of information between the different organs of the organism (i.e., autopoietic information). ${ }^{5}$

The evolution of the autopoietic and homeostatic processes is a dynamic one, and seeks to reach an equilibrium state in the quest for stability. This involves cycles of development and adaptability, accompanied by cycles of instability (Shkliarevsky 2007). Reaching equilibrium does not mean that the system exists in a static state. Rather, once at that state, the organism will seek to maintain it by responding to disruptions to the equilibrium. That is, the maintenance of the equilibrium is a dynamic process. The maintenance of equilibrium is achieved through the process of feedback control. ${ }^{6}$

Human homeostasis is illustrated by the body's need to preserve its temperature. Normal body temperature fluctuates around $36.8^{\circ}$ Celsius (Mackowiak, Wasserman and Levine 1992) - a value controlled by the brain. This value, however, is not universal. For example, it varies with (i) the site of measurement and gender (Sund-Levander, Forsberg and Wahren 2002), (ii) age (Günes and Zaybak 2008), (iii) race (Günes and Zaybak 2008), (iv) levels of physical activity (McGann et al. 1993), and (v) time of day measurement is taken (Mackowiak, Wasserman and Levine 1992). Other variables that influence body temperature include such things as hormones, exposure, and disease.

Information about the variables leading to fluctuations in the body's temperature is communicated from different organs (or sub-systems) in the body to the brain by the bloodstream. The brain, in turn, determines the best course of action for returning body temperature to the homeostatic plateau (i.e., the range between high and low body temperature levels). As either of the extremes is approached, corrective action (through a process called negative feedback) returns the system to the normal range (Homeostasis 2010). Thus, we have varieties of "normal" body temperature that display, on average, a mean temperature of a certain value, with a given range of homeostatic plateaus depending on any given number of conditions.

\subsection{The Legal System (the Autopoietic Process)}

As Luhmann (2004) and Teubner (1993) observed, legal institutions and the laws they produce also operate as a system. A legal system is formed by the State to serve particular functions, such as the regulation of human behaviour, in particular contexts. To achieve its

\footnotetext{
5 Of importance to our purposes, Cannon (1932, pp. 304-305) suggested that homeostasis may also have applications in areas other than the field of biology so that "an examination of the self-righting methods employed in the more complex living beings may offer hints for improving and perfecting the methods which still operate ineffectively and unsatisfactorily."

6 "Feedback" is a response within a system that influences the continued activity or productivity of that system. It is the control of a biological reaction by the end products of that reaction (Homeostasis 2010).
} 
functions, the legal system possesses particular mechanisms for the formation, reform, and enforcement of laws.

Laws are meant to be consistently applied in similar situations for the legal system to achieve and maintain the values of fairness and justice (in contrast to the random application of laws). This requires, therefore, a continuity of rules and doctrines.

Legal doctrines and rules do, of course, change and evolve in response to socioeconomic changes and demands. As Luhmann (2004, p. 258) explained, however, "it does not mean that the environment determines the legal system. Rather, the legal system notices defects only in its own devices and fixes them with its own means." In effect, therefore, the legal system evolves by reproducing itself so that the system's consistency and stability can be maintained.

The legal system's experience with the transfer pricing regime illustrates this process. In the early part of the $20^{\text {th }}$ century, the international community, through a transgovernmental network (the predecessor of the Organization for Economic Co-operation and Development (OECD)), joined in efforts to coordinate national policies to deal with the problem of transfer pricing. ${ }^{7}$ Members of the organisation formulated the Arm's Length Principle (ALP), ${ }^{8}$ which was incorporated into the national laws of the respective member states. The ALP is applied, predominantly, in accordance with the OECD's Transfer Pricing Guidelines (TPG), ${ }^{9}$ which are a form of soft law.

The purpose/function of the transfer pricing regime is to enable states to achieve two primary goals. On the one hand, the regime allows for the regulation of price setting for transactions between associated enterprises. ${ }^{10}$ On the other hand, it allows for the regulation of prices based on similar principles (i.e., the ALP and TPG) in order to minimise the risk of double taxation, which would otherwise arise if states apply different standards and rules. ${ }^{11}$

It is arguable that the ALP was, largely, an adequate legal principle formulated in light of market practices and socio-economic realities at the time of its conception (McLure 2006, p. 218). However, socio-economic changes and changes in market practices of multinational enterprises (MNEs), in particular, made the ALP's application increasingly

\footnotetext{
${ }^{7}$ For a historical discussion of the development of the transfer pricing regime see, e.g., Brian (1999). For a comprehensive discussion of the transfer pricing problem see, e.g., OECD (2001).

${ }^{8}$ In its current updated form, the ALP is set out in Article 9 of the OECD's Model Tax Convention on Income and on Capital 2005.

${ }^{9}$ For a general discussion of the ALP and TPG see OECD (2001). One should note that the TPG have influential (as oppose to legal) force only. Thus, different countries incorporate the TPG into their legal system differently. Some countries, such as the UK, expressly require by statute that the ALP be applied as far as possible in accordance with the TPG (in the UK this is set out in Paragraph 2 of Sch. 28AA of the ICTA 1988). Other countries, such as Canada, do not explicitly refer to the TPG by statute, but the revenue agency's interpretation of the statue will provide that the Revenue will follow, as far as possible, the TPG (see, e.g., the Canada Revenue Agency's Information Circular 87-2R).

${ }^{10}$ Regulation is deemed necessary because of the possibility that associated enterprises, carrying out cross-border transactions, could manipulate the tax position of the group as a whole by establishing "prices for transfers of products and services among related entities in a manner that shifts taxable revenues beyond the jurisdiction of the authorities" (Basu 2007, p. 135).

11 The OECD explained the problem of double taxation in the following terms: "any adjustment to the transfer price in one jurisdiction implies that a corresponding change in another jurisdiction is appropriate. However, if the other jurisdiction does not agree to make a corresponding adjustment the MNE [multi-national enterprise] group will be taxed twice on this part of its profits" (OECD 2001, Paragraph 12, Preface).
} 
complicated and unworkable. ${ }^{12}$ These led to pressures for reform, and prompted some to argue for a complete break from the ALP (see, e.g., Sadiq 2001).

The OECD noticed the challenges to the ALP and the calls for reform (OECD 2005). The OECD, however, responded with conventional reforms that sought to preserve the well established ALP, but added incremental modifications as to the manner in which the ALP is established (as set out in the TPG) (Basu 2007, p. 260). In other words, the system reproduced itself (this being the autopoietic process) in order to evolve in response to socioeconomic changes and pressures, but this self-reproduction was based on the existing legal doctrine. In so doing, the system preserved consistency and stability in the transfer pricing regime.

\section{THE AUTOPOIETIC AND HOMEOSTATIC PROCESSES AT WORK IN THE US}

\section{EQUITY MARKETS}

According to Tadesse (2004), financial markets and institutions serve two primary roles that, collectively, affect economic performance. These roles are the "allocation of risk capital through saving mobilization and risk pooling and sharing; and promotion of responsible governance and control through providing outside investors a variety of mechanisms for monitoring inside decision makers" (Tadesse 2004, p. 702).

\subsection{The mechanisms by which the system carries out its functions}

Focusing on the above functions of the capital markets, we see that these functions are carried out through two mechanisms: (i) the legal and regulatory regimes established by state and non-state institutions and (ii) self-regulation by shareholders, as a monitor and influence management performance.

While equity markets, as a system, worldwide carry out the same allocation and governance functions, the character of the mechanisms they utilize varies. Accordingly, we find that in each economy the equity markets may be subject to distinct regulatory institutions and laws. In addition, with respect to the mechanism of self-regulation by investors, differences between markets depend on the dominant form of equity ownership. Thus, for example, whereas the US and UK are said to have internalized the dispersed structure of equity ownership, investors in Continental Europe are said to have internalized a concentrated structure of equity ownership.

As Coffee (1999) noted, the problem with these mechanisms of self-regulation, under the traditional analysis, has been that neither form of public firm ownership at either of the extremes (i.e., diffused or concentrated) is efficient and the choice of either extreme involves a trade-off between improved monitoring of management, on the one hand, and liquid and efficient markets, on the other.

Hence, while the concentrated ownership model has the advantage of enabling equity owners to monitor and influence management (the governance function), its disadvantage is that it does not allow for sufficient liquidity in the equity markets and, as a result, it does not

\footnotetext{
${ }^{12}$ These changes include, inter alia, (i) globalization ( facilitated by the advent of new technologies, which led to changing corporate practices and arrangements); (ii) the emergence of new technology-based industries (such as e-commerce); (iii) a growing importance of international trade of services and intangible products; (iv) increase in international trade between related parties, whose operations have become increasingly integrated, and who often trade services that have no comparable external market; (v) increase in foreign direct investment (FDI). The relevant implications of these changes are the challenges they have been creating for application of the ALP (McLure 2006, p. 219-20).
} 
accommodate market mechanisms such as the market for corporate control (the allocation function). At the other extreme is the dispersed ownership model that has the advantage of facilitating liquidity and market mechanisms such as the market for corporate control (the allocation function), but fails to provide equity holders with sufficient control to monitor management since ownership is minimal and limited (the governance function).

\subsection{The move towards the market oriented blockholder model in the US}

In a recent article, Pichhadze (2010) identifies that the US equity markets have been evolving from concentrated ownership to "dispersed" ownership to the MOBM. This evolutionary trend is overlooked by the traditional and dominant theories in both academic (Pichhadze 2010, pp. 71-72) and regulatory ${ }^{13}$ circles, where the assumption is that the ownership pattern in the typical American firm is dispersed.

The significance of the trend towards the MOBM is that it makes possible for the equity markets to effectively and efficiently perform their dual function of facilitating liquidity, ${ }^{14}$ on the one hand, and providing for enhanced monitoring of corporate managers, on the other. ${ }^{15}$ Moreover, the MOBM sets out conditions that facilitate market mechanisms such as corporate control transactions. ${ }^{16}$

Pichhadze (2010) also identifies the national and international implications of the gravitation towards the MOBM. First, at the national level in the US, awareness of this trend highlights the need to re-evaluate one of the core fundamental pillars of American Securities regulation - that the ownership pattern in that country is diffused. Second, Pichhadze also identifies that other economies can be expected to follow the trend towards the MOBM. Consequently, if a global move towards the MOBM does materialize, this could facilitate a "functional convergence" of international corporate governance standards, policies, and regulatory approaches. Such convergence is arguably desirable because it could facilitate, and better accommodate, the current and future needs of the global financial landscape.

\subsubsection{The complex environment within which the capital market system operates}

The capital markets, viewed as a system, operate within a complex environment (with vertical and horizontal dimensions). It is engulfed by larger systems, such as the financial markets. Themselves, they subsume smaller systems, such as the equity markets, corporations, and investors. While these relationships are vertically (and horizontally) related, there are also systems that exist outside of this relationship, such as the legal system and the political system (i.e., externally related systems). Awareness of this environment is critical given that other systems can, and do, affect how the capital markets operate, and such

${ }^{13}$ As Sargent and Honabach (2009), for example, observed in the context of securities regulation in the US, "[ $\left.t\right]$ he SEC's proxy rules derive directly from the Berle-Means description of the public corporation and the belief that managerialism represented a threat to public shareholders." This view still represents the working hypothesis for the Securities and Exchange Commission (SEC) (see, e.g., Facilitating Shareholder Director Nominations, 17 CFR Parts 200, 232, 240, 249 and 274 [Release Nos. 33-904660089; IC-28765; File No. S7-10-09))

${ }^{14}$ One may question how a blockholder ownership pattern creates liquidity in the capital markets. To understand this, one should note that the emergent blockholder in the American equity markets is the institutional investor. Despite this the American equity markets are described in economic and financial literature as been being liquid.

${ }^{15}$ Coffee (1999, p. 648) introduced these two features of the polar ownership structures as tradeoffs. Under the MOBM, however, these features are complements rather than tradeoffs.

${ }^{16}$ This is important because economies characterized as having concentrated or blockholder modes of ownership are generally said to have a weak market for corporate control (see, e.g., Bebchuk and Hamdani 2009; Bebchuk and Roe 1999; Roe 1998-1999). Control transactions and listing of shares on an exchange are two ways that allow firms to choose their preferred governance systems (Goergen and Renneboog 2008). 
influences are particularly important for the understanding of the markets' gravitation towards the MOBM.

The external and internal influences, and their effects, on the US capital markets as well as the processes by which these markets react to such influences are described in greater detail below through the use of systems analysis. In doing so, the analysis assists in filling gaps in the literature. To meet these gaps, commentators suggested that we need to recognize the relevance and importance of viewing corporate governance issues within their sociological and transnational contexts. Consider, for example, the following comments by Zumbansen (2010, p. 21),

\begin{abstract}
$\ldots$ in the case of corporate governance regulation, many of today's regulatory regimes are irreversibly transnational and hybrid in nature. While we continue to study them through nationally oriented textbooks and case law, we soon learn how the rules and instruments we are dealing with are products of a far-reaching, fundamental transformation of the regulatory landscape. As corporate law is being shaped by a complex mix of public, private, state- and nonstate-based norms, principles and rules, generated, disseminated and monitored by a diverse set of actors and experts, even the most casual look at today's corporate governance debates reveals two important aspects: one is the way in which the analysis of contemporary corporate governance regulation can help us become sensitive to the emerging, new framework within which corporate governance rules are evolving, a framework which is constituted by a combination of local and transnational actors and norms, connected through 'networks' and migrating standards.
\end{abstract}

Similarly, Sir Cadbury (Claessens 2003, p. v) noted,

Corporations work within a governance framework. That framework is set by law, by regulations, by the corporation's own constitution, by those who own and fund them, and by the expectations of those they serve. The framework will differ country by country, since it owes much to history and culture and it involves both rules and institutions. Its effectiveness depends on its coherence and on the degree of reliance which can be placed on its constituent parts. The governance framework also changes shape and develops through time. ... how little we know about the nature of these changes and how their direction might be influenced.

\title{
3.2.2 The gravitation towards the MOBM: an unfolding of the system's autopoietic and homeostatic processes
}

As noted earlier, the functioning of the equity markets (when viewed as a system) is continuously affected by influences that are external and/or internal to them. In what follows, I identify a number of factors impacting the vertical and horizontal dimensions/relationships that have facilitated the trend towards the MOBM in the American equity markets. Before doing this, however, it would be useful to describe the operation of the equity markets in simple terms.

We can think of the equity markets in the following way. Let us assume that equity investors (as a group) make up a system $\left(\mathrm{O}_{0}\right)$. Assume further that the publicly traded firm is likened to a system $\left(\mathrm{O}_{1}\right)$ that is, inter alia, made up of $\mathrm{O}_{0}$ and is subsisting within a larger system, such as the equity markets $\left(\mathrm{O}_{2}\right)$ (which in itself is subsisting within a larger system, such as the capital markets $\left(\mathrm{O}_{3}\right)$ and the financial system $\left(\mathrm{O}_{4}\right)$ etc.). Moreover, assume that shares, representing equity stakes in the public firm, are the gradients subject to the regulatory processes within $\mathrm{O}_{1}$ and $\mathrm{O}_{2} \cdot{ }^{17}$ Adopting a bird's eye view to this system, Pichhadze observed an evolutionary trend in the ownership of public firms in the American equity markets towards the MOBM,

\footnotetext{
17 This is consistent with Fama's observation that " $[\mathrm{t}]$ he primary role of the capital market is allocation of ownership of the economy's capital stock" (Fama 1970, p. 383).
} 
This trend gives rise, inter alia, to two related observations (Pichhadze 2010, pp. 8284). First, there appears to be a market-driven self-regulatory mechanism at the level of the equity markets that tends to concentrate ownership into the hands of blockholders. It is suggested that this is the homeostatic or self-regulatory process described above. Second, this self-regulatory process is supplemented and facilitated by information flows. It is suggested that this is the autopoietic or self-reproducing process described above. Let us consider each of these processes.

\subsubsection{The regulations of share ownership}

The history of the US equity markets shows that these markets evolved in three stages vis-àvis ownership patterns. During the infancy of the markets, ownership was concentrated in the hands of a number of industrial elites. The pattern of ownership started to change during the early decades of the $20^{\text {th }}$ century, where we notice that the ownership pattern in large corporations experienced fragmentation to the extent that no single shareholder could influence the management of the corporation. The third stage, which started in the post World War II era, involved the institutionalization of the US equity markets. This process saw the re-concentration of ownership of the previously fragmented large firms into the hands of fiduciary investors that managed large pools of capital on behalf of individual investors. These fiduciary investors are institutional investors and include such institutions as mutual funds, public and private pension funds, and insurance companies (for a general discussion see Pichhadze 2010).

We can describe this evolutionary trend as one that moved from concentrated ownership (i.e., stage one), to "dispersed" ownership (i.e., stage two), to the MOBM (i.e., stage three). As we can see, as the capital markets grew in complexity and matured, market forces have been combining the two extreme poles of ownership (i.e., concentrated and diffused) into a hybrid structure that affords both liquidity in the capital markets and increased monitoring by blockholders. This coupling of ownership structures allows for the functioning of market mechanisms such as the market for corporate control.

The trend towards the MOBM can, therefore, be thought of in terms of the homeostatic or self-regulatory process of the equity markets vis-à-vis share ownership, which attempts to maintain the levels of corporate ownership within certain limits at $\mathrm{O}_{1}$ and $\mathrm{O}_{2}$ (i.e., the public firm and the equity markets, respectively). These limits correspond to the blockholder levels of ownership and represent the state of stability towards which the markets are moving - levels that allow the markets to perform their dual functions of allocation and governance. ${ }^{18}$ This range, therefore, can be said to represent the homeostatic plateau or "normal" range of voting share ownership.

What happens when a deviation from the "normal" range is detected by the system? The recent wave of private equity (PE) activity provides an example of this. PE transactions, like their 1980s counterparts, the leverage buyout (LBO) transactions, are a partnership between active investors and institutional investors (see, e.g., Pound 1992). As an ownership

\footnotetext{
${ }^{18}$ The study by Berry, Fields and Wilkins (2006) is illustrative of this point. The study followed 109 young firms (defined as three years of age or younger at the time of the IPO) for a period of eleven years following the IPO. Their results show that governance mechanisms in the firm (which include, inter alia, CEO ownership, board independence, venture capitalist directors, total outside board membership, venture capitalist ownership, incentive-based pay, and unaffiliated block holdings) work in tandem in order to minimize agency costs that arise as a result from the reduction in managerial stock ownership in the post-IPO term. Thus, they found that as CEO and venture capitalists ownership declines after the firms in their study went public, the increase in monitoring by independent board membership and outside blockholders (a category that includes both institutional investors and individual investors) offset the potential increase in agency costs of equity.
} 
model, they are said to present a superior ownership structure to the public corporations because they offer (i) improved corporate governance, (ii) ownership that is concentrated in the hands of active owners or investors (accompanied by strong managerial incentives), and (iii) efficient capital structure (Jensen 1989, 2007; Morgan Stanley Roundtable 2006).

$\mathrm{PE}$ and LBO transactions, much like active investing, is the process of trading based on information - information about inefficiencies in the marketplace. These transactions, however, also represent the market's response to the fragmented nature of the public corporations. ${ }^{19}$ Thus, when information about inefficiencies resulting from the diffusion of ownership is transmitted in the market, active investors participate in the takeover environment, provided that these investment opportunities can be translated into increased returns on investment. They do this by taking the ownership of the target firm to the other extreme - concentrated ownership - with the intention of introducing operational efficiencies into these firms and later returning them to the public markets by way of initial public offering.

The lesson from these transactions for corporate governance, according to Elson (2007), is that we need blockholder representation on boards. Phrased differently, blockholder ownership can be thought of as representing the stable state of corporate public ownership.

This analysis can be applied at the international level as well. Claessens (2003, p. 6) observed, in the context of corporate governance analysis, that "[a]n easier way to ask the question of what corporate governance means is to take the functional approach. This approach recognizes that financial services come in many forms, but that if the services are unbundled, most, if not all, key elements are similar." We can adopt this functional approach to the analysis of the homeostatic plateau, which is a dynamic range and economy specific.

While the particular value of the homeostatic plateau for any given economy may depend on any number of variables, much like the thermodynamic regulation above, the process will result in a number of "normal" ranges that, while economy specific, should yield similar results. ${ }^{20}$ As such, it is submitted that the MOBM can accommodate a variety of economic structures (or varieties of capitalism).

In addition, the fact that the MOBM is the emerging ownership pattern in the US shows us that market forces in the US are driving ownership patterns towards what can be said to be an optimal ownership structure that is also socially most favourable or optimal.

Social optimality in the context of the corporation refers to the notion that the shareholders' representatives serve the shareholders' interest (Grossman and Hart 1980). One

\footnotetext{
${ }^{19}$ As Pound (1992, p. 8) observed, "[o]versight by entrepreneurial insurgent investors has been generated by two central (and related) features of U.S. capital markets: their fragmentation and their openness to innovation."

${ }^{20}$ To use the terminology of the thermodynamic example above, economies may differ based on their (i) gender, i.e., type of legal system (e.g., Common Law vs. Continental Law); (ii) race, i.e., geographic location (e.g., Europe vs. North America vs. Asia-Pacific); (iii) age, i.e., stage of economic development (e.g., emerging vs. developing vs. developed); and (iv) level of physical activity, i.e., state of economy (e.g., expansionary vs. recessionary periods). Yet, much like the thermodynamic homeostatic plateau, the market will attempt to restore the levels of ownership to ownership homeostatic plateau once a disturbance is communicated. Disturbance in this case translates into a deviation from the economy specific range of block holdings towards either extreme form of ownership (i.e., diffused or concentrated). The assumes a frictionless process, where friction in this context means political and/or other influences that may serve to act as an obstacle to the self-regulatory process. Roe (1997, p. 8) provide an example of how the political system can serve as friction to the process. He observed, in the context of the US, that "[p]olitics, in the form of laws and regulations ... played a key role in fragmenting stock ownership beyond what was required" [emphasis added].
} 
way of ensuring that this social welfare is met in the context of the corporation is through the monitoring of managers. The problem is that absent anyone owning sufficient stakes in the corporation, monitoring is left to market-mechanisms such as takeovers (Grossman and Hart 1980). Market forces and socio-economic realities, however, created a venue for the promotion of social optimality in the corporation. They have paved the way for the reconcentration of equity ownership into the hands of institutional investors, who have sufficient stake in the corporation and, therefore, an interest in monitoring corporate managers.

Institutional investors, as blockholders, and takeovers are also two key features in the MOBM. They promote efficiency and liquidity in the capital markets while enabling the increased monitoring of corporate managers. In addition, given that a feature of the MOBM is the presence of a blockholder (whether an institutional or not), it points to the observation that market forces, in gravitating towards the MOBM, are attempting to reduce the suboptimality created by the diffused ownership pattern of corporate ownership. ${ }^{21}$

\title{
3.2.2.2 The role of information at the inter-system level
}

Activity in the capital markets is also influenced by information other than that which exists at the intra-system level (e.g., information about shares and companies as described above). This information is that which operates at the inter-systems level - that is, information between the capital markets and other systems (such as the legal system and the political system) that influence, and are influenced by, the markets. The need for understanding this relationship was expressed by Claessens (2003, p. 6),

\begin{abstract}
Institutions do not arise in a vacuum and are affected by the rules in the country or the world. Similarly, laws and rules are affected by the country's institutional setup. In the end, both institutions and rules are endogenous to other factors and conditions in the country. Among these, ownership structures and the role of the state matter for the evolution of institutions and rules through the political economy process. Shleifer and Vishny (1997, p. 738) [referring to Andrei Shleifer and Robert Vishny, "A Survey of Corporate Governance”, 52 Journal of Finance 2, 1997, 737] take a dynamic perspective by stating: "Corporate governance mechanisms are economic and legal institutions that can be altered through political process." This dynamic aspect is very relevant in a cross-country review, but has received much less attention from researchers to date.
\end{abstract}

The inter-systems type of information supported the growth and maturity of the equity markets and involved the gradual and progressive internalization of input in order for the framework, within which the capital markets operate, to achieve stability. Stability here is achieved through the continuous monitoring by the system of the changes to its environment, and the making of updates or corrections to its framework in order to respond to changing socio-economic conditions. This information had to be benchmarked against prior knowledge of the actors in order to facilitate growth towards the MOBM. This is the self-reproducing (autopoietic) process that supplements and facilitates the self-regulatory (homeostatic) process in the capital markets just described.

A number of examples will illustrate how the autopoietic process in the US facilitated the concentration of equity ownership into the hands of institutional investors and, therefore, the progress towards the MOBM. The first example is that of The Employee Retirement

\footnotetext{
${ }^{21}$ As Bebchuk and Zingales (2000, p. 57) observed, "the incidence of IPOs ... is larger in the United States than in other advanced economies ... While this large incidence of IPOs is generally taken to be a socially optimal outcome, our results suggest the possibility that this incidence is excessive" [emphasis added]. The assumption in the Bebchuk and Zingales analysis appears to be that going public automatically translates into the assumption of diffused ownership structure for the corporation (i.e., atomistic share ownership).
} 
Income Security Act of 1974 (ERISA). The US government, through Congress, observed a dramatic shift in the character of share ownership in the US. This shift was from individual ownership of stock to institutional ownership of stock. ${ }^{22}$ Given the socio-economic impact of this shift in share ownership, the US government adopted measures to facilitate it. One such measure is The Employee Retirement Income Security Act of 1974 (ERISA) - a US federal statute that sets minimum standards for most voluntarily established pension and health plans.

In this context, it was observed, that the dramatic shift in share ownership "has not been the creation of the Congress, and certainly not the SEC, but rather of other economic and social forces ... although Congress has from time-to-time stimulated the move towards increased institutionalization of equity investment through various income tax provisions, as it did just recently with the Employee Retirement Income Security Act of 1974" (Garrett 1975). Through ERISA, the US government also endorsed shareholder activism by pension funds - that is, the political system facilitated the corporate governance function by certain actors in the equity markets through the tools of policy. This was done through the Department of Labor's observation that shareholder activism by fiduciaries of portfolio firms is consistent with their fiduciary obligations. ${ }^{23}$

The ERISA example provides an illustration for the situation where the political system observes a trend within the economy (i.e., the institutionalization of the equity markets) and decides to accommodate it by updating the legal framework for the purpose of further facilitating the trend.

The second example illustrates how the legal system responded to interest group pressures by updating the legal framework in order to accommodate the new reality of institutional investors as blockholders. Involves the proxy rules in the US. The proxy rules found in section 14 of the Securities and Exchange Act of 1934 are intended to protect fair voting in the corporation (Bloomenthal and Wolff 2008). As the size and role of institutional investors in the equity markets grew, some institutional investors, led by the California Public Employees Retirement System (CalPERS), criticized the proxy rules for impeding fuller shareholder participation in corporate affairs and, as a result, sought that the SEC amend the rules. In their argument for these amendments CalPERS argued that the rules "discourage responsible, long-term investors from playing a meaningful role in the governments of public corporations" (Bloomenthal and Wolff 2008). ${ }^{24}$

The dialogue between the SEC and institutional investors in the area of proxy rules ${ }^{25}$ reflects, as in the ALP example provided above, the result of information exchange between

\footnotetext{
${ }^{22}$ For more on the process of the institutionalization of the US equity markets see Pichhadze (2010, p. 73-79).

${ }^{23} 29$ CFR 2509.94-2 - Interpretive bulletin relating to written statements of investment policy, including proxy voting policy or guidelines (available at http://www.dol.gov/dol/allcfr/Title 29/Part 2509/29CFR2509.942.htm) (date accessed, February 1, 2010).

${ }^{24}$ It is interesting to note that in their arguments for amending the proxy rules, CalPERS argued the significance of long-term investment horizon of institutional investors. This is of note given that it has been argued that '[i]nstitutional investors have never been the paragons of long-term investing that some claim to be' (Jacoby 2008, p. 24). See also Holmstrom and Kaplan (2001).

${ }^{25}$ Sargent and Honabach (2009) observed, inter alia, that since the late 1980s, institutional investors, under the leadership of such actors as CalPERS, sought to amend the proxy rules in order to achieve three objectives: (i) to protect the market for corporate control by removing anti-takeover measures adopted by managements and boards; (ii) to increase shareholder input into corporate decision-making; and (iii) to influence the election of corporate boards). According to Sargent and Honabach, institutional investors have been successful in their efforts to influence the SEC and US Congress in amending the proxy rules to facilitate the first of two of these goals. The third objective is currently in the proposal stages (i.e., Facilitating Shareholder Director
} 
the market (and its participants) and the SEC (or the legal system). Here, the SEC was faced with challenges to the proxy rules stemming from the changing socio-economic landscape of the equity markets (i.e., the institutionalization of the financial markets and the reconcentration of equity ownership in institutional investors). The SEC responded to these challenges by amending its rules based on its own framework. ${ }^{26}$

This example illustrates how the legal system responded to interest group pressures by updating the legal framework in order to accommodate the new reality of institutional investors as blockholders.

\section{UNFOLDING ... BUT NOT YET A COMPLETED PROCESS}

At the outset of this article, it was noted the move towards a first-best corporate model is being unfolded. As the discussion showed, with the emergence of institutional investors as an influential blockholder in large public firms, the US markets have been gravitating towards the MOBM. This process, however, is not yet complete.

The reason is rooted in the legal system's failure to update some its definitions. More particularly, actors in the capital markets have recognized the growing role and importance of institutional investors in the capital markets qua blockholders, both nationally and internationally. Nevertheless, the legal system, though facilitating this important development and taking note of it, has not yet updated its basic definitions to acknowledge this process.

Evidence of the sluggishness in updating the basic definitions can be found in American securities regulation. While blockholders are a feature of the US capital markets, in firms of all sizes (Pichhadze 2010), the underlying premise of US securities regulation is that the ownership pattern in the US is one that is properly characterized as diffused (Pichhadze 2010, p. 88). This creates a difficulty for policy making considering different ownership structures (whether diffused, concentrated, or blockholder) create different opportunities for policy making. Those different opportunities, however, require different policy considerations (Bebchuk and Hamdani 2009).

Consequently, by (i) failing to recognize that the appropriate ownership model in the US is in fact the MOBM and (ii) continuing to promote policy and regulatory initiatives that are premised on the (invalid) notion that the ownership pattern in the US is diffused, there is the risk that a distortion is being introduced into the regulatory system by in appropriately applying the same regulatory system to two ownership patterns (i.e., MOBM and dispersed). Phrased differently, by failing to make a proper diagnosis of a symptom, we are offering inappropriate treatment. In the context of the capital markets and policy making, approaches to corporate governance policy based on inappropriate foundations may result in policy makers inadvertently contributing to the introduction of a systemic risk into the national, as well as, the international financial systems.

Nominations, 17 CFR Parts 200, 232, 240, 249 and 274 [Release Nos. 33-904660089; IC-28765; File No. S7-1009]).

${ }^{26}$ A similar example for the autopoietic process, where the political and legal systems observe and update their framework due to changing socio-economic changes in the economy vis-à-vis institutional investors, can be found in the UK. There it was observed that given the institutionalization of the UK markets, "a regulatory structure which reflects the interests of institutional shareholders, protecting them against both managerial entrenchment and acquirer opportunism is perhaps a natural growth" (Davies and Hopt 2004, p. 190). 
The type of systemic risk I am referring to in this context results from long-term imbalances introduced into the regulatory framework by regulators. What does "imbalance" mean in the context of systemic risk in the capital markets? Schapiro (2009) noted that we need to distinguish between two types of systemic risk. First, there is the near-term systemic risk that results from seizures or cascading failures. Second, there is the longer-term risk that results from the unintentional bias towards larger institutions at the expense of smaller participants. Consequently, Schapiro (2009) noted, "[w]e must be very careful that our efforts to protect the system from near-term systemic seizures do not inadvertently result in a longterm systemic imbalance." In addition, Schapiro (2009) noted that in the context of these types of systemic risk we need to, inter alia, "address structural imbalances that facilitate the development of systemic risk by closing gaps in regulations ..." To adequately meet such challenges, however, we must first observe the regulatory gaps currently embedded in the system.

As we have seen with the examples mentioned above, it is in the context of corporate governance that we see examples of the seeds of structural imbalance in the overall regulatory framework of securities regulation. These imbalances are capable of translating themselves into a regulatory systemic risk if ignored by policy makers. These imbalances result from the introduction, and carrying forward, of distortions into the regulatory framework. Moreover, a student of the area will be aware that these distortions, and the imbalance they may give rise to, extend beyond the proxy rules and affect other aspects of the regulatory framework. This is because corporate ownership within a given economy touches on a number of key governance arrangements ${ }^{27}$ and impacts the overall regulatory framework of securities regulation.

Consequently, the observation vis-à-vis changing investor demographics (i.e., the growing size of institutional holdings and the diminishing size of individual holdings) and the realization that the MOBM accurately portrays the ownership pattern in the American equity markets, have broad implications to the regulatory framework applicable to these markets. Ignoring these distortions might give rise to regulatory systemic risk.

These distortions assume greater complexity when we move from the national arena to the international and transnational settings. Here, it has been noted that "[i]n its broadest sense, corporate governance is concerned with holding the balance between economic and social goals and between individuals and communal goals. ... The aim is to align as nearly as possible the interests of individuals, of corporations, and of society" (Claessens 2003, p. vii). One way of achieving these goals is through the promotion of international corporate governance standards - standards that started as national codes and later became international guidelines (Claessens 2003, p. vii). Key players in the promotion of these standards are institutional investors (Claessens 2003, pp. v-vi).

Institutional investors are instrumental in the introduction of codes of corporate governance. Following the production of these codes of best corporate governance practices, they promote their adoption by their portfolio firms. Institutional investors are also relied

\footnotetext{
${ }^{27}$ For example, ownership structures affect several key governance arrangements and, as such, the regulatory framework that defines and affects them. For example, it has been observed that ownership structures affect arrangements such as "those regulating control contests, voting procedures, the allocation of power between directors and shareholders, the distribution of power among shareholders ... director independence, and corporate transactions that may divert value to insiders" (Bebchuk \& Hamdani 2009, p. 1270). In addition, it has been observed that ownership structure affects such matters as (i) takeovers and defensive measures adopted by firms to thwart such activity, (ii) conflict of interest rules and related party rules, and (iii) significant corporate action and disclosure rules (Kraakman et al. 2004).
} 
upon by governmental agencies for the adoption and introduction of codes recommended by these governmental agencies to institutional investors' portfolio firms (Mallin 2007, pp. 8285). Thus, as Zumbansen (2010, p. 21) observed, corporate governance regulation can be seen as "transnational and hybrid in nature." This reliance on institutional investors poses a definitional or characterization challenge to policy making.

The definitional challenge posed by institutional investors stems from their treatment in the literature. Generally speaking, institutional investors are credited for, and trusted with, the promotion of corporate governance standards both nationally and internationally (Cadbury 2003). ${ }^{28}$ Leading these efforts are, among others, American institutional investors who are said to promote US-style governance around the globe (Gilson 2004, p. 147). In addition, institutional investors are also credited with the reduction of public distrust in large firms (Stimson 1925, pp. 135-136). ${ }^{29}$ As an article in one of the United Nations Environment Programme Finance Initiative's (UNEP FI) newsletters notes,

Policymakers around the world have a historic window of opportunity to shepherd a new policy of growth that transcends outmoded divides between at the anti-capitalism of the traditional left and the laissez-faire corporatism of the traditional right. The reason is the rise of mass ownership.

Through pension, insurance and savings institutions, millions of citizens-savers are gradually inheriting potent stakes in the commanding heights of enterprise ... (Davis 2005, p. 8)

Yet, while professing to, inter alia, promote dispersed ownership (i.e., US-style governance), the MOBM analysis, in this article and in Pichhadze (2010), has demonstrated that institutional investors are the new blockholder in the American equity markets.

The two conflicting ways to characterize or define the role of institutional investors in the equity markets (i.e., as agents for the diffusion ownership that are relied upon for the introduction and dissemination of improved corporate governance standards, on the one hand, and as financial blockholders in public firms, on the other) present a challenge for policymaking. This challenge also represents the point where economic analysis and legal analysis yield different results and, thus, depart from one another.

From an economic analysis perspective, whether we view them as blockholders or agents for the diffusion of ownership, institutional investors, as a powerful financial actor in the capital markets, offer a potential vehicle for the improvement of corporate governance practices. That is, institutional investors, as blockholders and transnational agents, possess the power to introduce the requisite change at both the national and international levels. Yet, this change may give rise to a potential conflict.

The conflict could stem from the source of the change. Namely, whether the source of change being the institutional investor or the State. If the proposed change originates with the institutional investor, it does not automatically imply that this proposed change is for the benefit of all the shareholders of the corporation, as the interests of the institutional investors are not necessarily identical to those of other shareholders. If, on the other hand, the change originates from the State, the State may need to rely on the institutional investor to enforce

\footnotetext{
${ }^{28}$ See Hansmann and Kraakman (2004) noting, at 49-50, that institutional investors, in general, and mutual funds and pension funds, in particular, "not only give effective voice to shareholder interest, but promote in particular the interests of dispersed public shareholders rather than those of controlling shareholders or corporate insiders.... Moreover, the new activist shareholder-oriented institutions are today acting increasingly on an international scale.").

${ }^{29}$ If that was the case, the reduction in distrust was apparently accompanied by (i) a retraction from laissez faire economic principles and (ii) increased governmental and political influences on commercial activities (Pell 1925).
} 
compliance by portfolio firms with the proposed change. When the State does this, it does so based on the notion that the institutional investor is a powerful and influential blockholder in the markets.

While there may not be conflict per se in the reliance of the State on the institutional investor qua blockholder, it does lead us to question the fundamental assumption of the ownership pattern being dispersed under corporate and securities laws in countries such as the US. Such questioning of fundamental assumptions, in turn, leads to the need for revisiting the regulatory framework, as noted earlier, for the purposes of updating its definitions in order to give effect to the fact that the ownership pattern is the MOBM.

\section{CONCLUSION}

This article sought to show how market forces are driving an evolutionary trend towards the MOBM, which represents a first-best corporate governance solution, by actively combining two extreme forms of ownership (concentrated and diffused) into a hybrid ownership structure that affords both increased monitoring of management and the promotion of efficient and liquid markets. We arrive at the MOBM by adopting a holistic view of the capital markets and the use of sociological methodologies. As the analysis showed the trend towards the MOBM was facilitated by information and two types of processes: the homeostatic process and the autopoietic process.

This type of analysis also reveals that progress towards the MOBM has been unfolding but it is not yet complete. This is due to the fact that the legal system has not, yet, updated its basic definitions - definitions that are required to be updated in order to facilitate stability in the system's framework. Stability also translates into the minimization of the potential to introduce a systemic risk secondary to the current inability of policy makers to take notice of trends in the markets that they regulate.

Taking notice of the MOBM trend by regulators and policy makers has national and international implications. Such regulatory recognition by policymakers should yield, at least, two results. First, it would facilitate an update of the regulatory framework of the securities markets so that policies will meet the challenges presented by the blockholder mode of ownership. In addition, given that the US is a special case of the blockholder mode of ownership - the MOBM - traditional analysis of the blockholder model needs to be tailored to that situation, as opposed to relying on approaches currently available in academic and regulatory circles. This is because the traditional analysis does not necessarily accommodate the MOBM. For instance, the traditional analysis holds that that the blockholder ownership pattern does not allow for market mechanisms such as the market for corporate control, whereas, under the MOBM analysis, the blockholder mode of ownership in the US relies upon market mechanisms for the maintenance of the homeostatic plateau in the ownership of the public firm.

Internationally, the MOBM facilitates a functional convergence on corporate governance issues given that the MOBM aligns the US more closely with other economies economies that are in the process of adopting measures for the introduction of market oriented instruments into their respective markets so as to move closer to the US. Such a functional convergence may facilitate the harmonization of corporate governance standards internationally. However, the realization of a globally harmonized approach to corporate governance necessitates policy makers to recognize the evolving trends in the global marketplace so that the measures they adopt do in fact reduce the systemic risk in their respective markets rather than propagate them. 
This article is timely and relevant in the context of the 21 st century's first posteconomic crisis era. Recent events in the global financial sector have resulted in heightened public and regulatory interest in increased regulation of the financial markets and the extension of regulation into new areas (Expert Panel, 2009: 11; Schapiro, 2009). While much of the discourse on the issue nowadays relates to financial intermediaries (e.g., investment houses) and certain financial products (e.g., over-the-counter derivatives) that could introduce or enhance systemic risk in the capital markets, imbalance in the regulatory framework could be induced in other areas (i.e., regulations that do not mirror neatly the realities in the marketplace).

I highlighted the need for regulators to be cognizant of long-term trends in the capital markets in order to minimize the possibility of regulators introducing a system risk into the markets (i.e., regulatory systemic risk). Such a cautionary approach is mandated in order to avoid (i) the introduction of distortions into the novel financial framework contemplated by policymakers and/or (ii) the elimination of existing distortions should this novel framework be premised on the existing one.

\section{REFERENCES:}

Homeostasis. In 2009. Britannica online. Chicago, Ill. : Encyclopaedia Britannica, Inc.: , http://www.search.eb.com/eb/article-9040879 (accessed April 8, 2009).

Morgan Stanley roundtable on private equity and its import for public companies. 2006. Journal of Applied Corporate Finance 18, (3): 8-37.

Audi, Robert. 1999. The Cambridge dictionary of philosophy. 2nd ed. Cambridge, U.K; New York: Cambridge University Press.

Basu, Subhajit. 2007. Global perspectives on e-commerce taxation law. Markets and the law. Aldershot, England: Ashgate.

Bebchuk, Lucian Arye, and Mark J. Roe. 1999. A theory of path dependence in corporate ownership and governance. Stanford Law Review 52, (1) (11/01): 127-70.

Bebchuk, Lucian A., and Assaf Hamdani. 2009. The elusive quest for global governance standards. University of Pennsylvania Law Review 157, (5) (05): 1263-317.

Berry, T. K., L. Paige Fields, and M. S. Wilkins. 2006. The interaction among multiple governance mechanisms in young newly public firms. Journal of Corporate Finance 12, (3) (June, 2006): 449-66.

Bloomenthal, Harold S., and Samuel and Wolff. 2008. Part X. Proxy regulation, tender offers, and take-overs, chapter 24. Proxy regulation in Securities and federal corporate law. 2nd ed. Westlaw.

Bratton, William W., and Joseph A. McCahery. 2002. Comparative corporate governance and barriers to global cross reference. In Corporate governance regimes : Convergence and diversity., eds. Joseph A. McCahery, Piet Moerland, Theo Raaijmakers and Luc Renneboog, 23-55. Oxford; New York: Oxford University Press.

Cannon, Walter B. 1932. The wisdom of the body. The norton library. New York: W.W. Norton.

Claessens, Stijn. 2003. Corporate Governance and Development. 1 Focus.Online: http://www.gcgf.org/ifcext/cgf.nsf/Content/Focus_Notes 
Davies, Paul, and Klaus Hopt. 2004. Control transactions. In The anatomy of corporate law : A comparative and functional approach., eds. Reinier H. Kraakman, Paul Davies, Henry Hansmann, Gerard Hertig, Klaus J. Hopt, Hideki Kandra and Edward B. Rock, 157-191. Oxford; New York: Oxford University Press.

Durkheim, Emile. c1997. Suicide: A study in sociology. New York: Free Press.

Elson, Charles. 2007. The state of U.S. corporate governance: An interview with chales elson. Journal of Applied Corporate Finance 19, (1): 74-80.

Expert Panel on Securities Regulation in Canada. 2009. Creating an advantage in global capital markets. Ottawa, Ont.: Department of Finance Canada.

Fama, Eugene F. 1970. Efficient capital markets: A review of theory and empirical work. Journal of Finance 25, (2) (05): 383-417.

Goergen, M., and L. Renneboog. 2008. Contractual corporate governance. Journal of Corporate Finance 14, (3) (June, 2008): 166-82.

Grossman, Sanford J., and Oliver D. Hart. 1980. Takeover bids, the free-rider problem, and the theory of the corporation. The Bell Journal of Economics 11, (1) (Spring): 42-64.

Günes, Ülkü Yapucu, and Ayten Zaybak. 2008. Does the body temperature change in older people? Journal of Clinical Nursing 17, (17): 2284-7.

Holmstrom, Bengt, and Steven N. Kaplan. 2001. Corporate governance and merger activity in the united states: Making sense of the 1980s and 1990s. The Journal of Economic Perspectives 15, (2) (Spring): 121-44.

Jacoby, Sanford M. 2008. Finance and labor: Perspectives on risk, inequality, and democracy. Comparative Labor Law and Policy Journal 30, : 17-65.

Jensen, Michael C. 2007. The economic case for private equity (and some concerns) - pdf of keynote slides. SSRN eLibrary.

Jensen, Michael C. 1989. Eclipse of the public corporation. Harvard Business Review 67, (5) (/09Sep/Oct89): 61-74.

John C. Coffee Jr. 1999. The future as history: The prospects for global convergence in corporate governance and its implications. Northwestern University Law Review 93, (3): 641-707.

Luhmann, Niklas, Fatima Kastner, and Klaus A. Ziegert. 2004. Law as a social system. Oxford socio-legal studies. Oxford: Oxford University Press.

Mackowiak, P. A., S. S. Wasserman, and M. M. Levine. 1992. A critical appraisal of 98.6 degrees $\mathrm{F}$, the upper limit of the normal body temperature, and other legacies of carl reinhold august wunderlich. JAMA : The Journal of the American Medical Association 268, (12) (Sep 23-30): 1578-80.

Mallin, Chris A. c2007. Corporate governance. 2nd ed. ed. Oxford ;: Oxford University Press.

Maturana, Humberto R., and Francisco J. Varela. 1980. Autopoiesis and cognition : The realization of the living. Boston studies in the philosophy of science ; v. 42. Dordrecht, Holland; Boston: D. Reidel Pub. Co. 
McGann, K. P., G. S. Marion, L. Camp, and J. G. Spangler. 1993. The influence of gender and race on mean body temperature in a population of healthy older adults. Archives of Family Medicine 2, (12) (December 1): 1265-7.

McLure Jr., Charles, E. 2006. National tax rules and sovereignty. In Globalization: Encyclopaedia of trade., ed. Ashish K. Vaidya, 212-233. Santa Barbara, Calif: ABC-CLIO.

OECD. 2009. OECD sets out framework for overhaul of financial regulation. Online: http://www.oecd.org/document/44/0,3343,en_2649_37467_44180524_1_1_1_1,00.html.

OECD. 2009. Policy framework for effective and efficient financial regulation: OECD recommendation and principles. Online: http://www.oecd.org/dataoecd/18/53/44187223.pdf.

OECD. 2005. E-commerce: Transfer pricing and business profits taxation. OECD tax policy studies. Paris, France: OECD Publishing.

OECD, Taxation. 2001. Transfer pricing guidelines for multinational enterprises and tax administrations . Paris, France: OECD Publishing.

Pell, Herbert C.,Jr. 1925. Consequences of impersonal ownership. Proceedings of the Academy of Political Science in the City of New York 11, (3, Popular Ownership of Property: Its Newer Forms and Social Consequences) (Apr.): 70-4.

Pichhadze, Aviv. 2010. The nature of corporate ownership in the USA: The trend towards the market oriented blockholder model. Capital Markets Law Journal 5, (1): 63-88.

Pound, John. 1992. Raiders, targets, and politics: the history and future of American corporate control. Journal of Applied Corporate Finance 5, (3): 6-18.

Roe, Mark J. 1998-1999. German codetermination and German securities markets. Columbia Journal of European Law 5, (2): 199-212.

Roe, Mark J. 1997. The political roots of American corporate finance. Journal of Applied Corporate Finance 9, (4): 8-22.

Sadiq, Kerrie. 2001. Unitary taxation - the case for global formulary apportionment. Bulletin for International Fiscal Documentation 55, (7): 275-86.

Sargent, Mark A. And Dennis R. Honabach. 2009. Proxy Rules Handbook, § 1:1 Proxy Regulation and the Corporation Governance Debate. Westlaw.

Schapiro, Mary L. 2009. Testimony Concerning Regulation of Systemic Risk by Chairman Mary L. Schapiro. Before the United States Senate Committee on Banking, Housing and Urban Affairs, July 23, 2009. Online: http://www.sec.gov/news/testimony/2009/ts072309mls.htm

Shkliarevsky, Gennady. 2007. The paradox of observing, autopoiesis, and the future of social sciences. Systems Research and Behavioral Science 24, (3) (May\&sol; June 2007): 323-32.

Sund-Levander, Märtha, Christina Forsberg, and Lis Karin Wahren. 2002. Normal oral, rectal, tympanic and axillary body temperature in adult men and women: A systematic literature review. Scandinavian Journal of Caring Sciences 16, (2) (June 2002): 122-8.

Tadesse, Solomon. 2004. The allocation and monitoring role of capital markets: Theory and international evidence. Journal of Financial \& Quantitative Analysis 39, (4) (12): 701-30. 
Teubner, Gunther. 1993. Law as an autopoietic system. Oxford, UK; Cambridge, Mass., USA: Blackwell Publishers.

Wymeersch, Eddy. 2002. Convergence in Corporate Governance Patterns in Western Europe. In Corporate governance regimes : Convergence and diversity., eds. Joseph A. McCahery, Piet Moerland, Theo Raaijmakers and Luc Renneboog, 230. Oxford; New York: Oxford University Press.

Zumbansen, P. 2010. Transnational legal pluralism. CLPE Research Paper no. 01/2010. Online: http://ssrn.com/abstract=1542907. 